\title{
都市分散型水資源に関する一般市民と 行政等担当者の選好の比較検討
}

\author{
都 筑 良 明*n荒 巻 俊 也**
}

\section{Comparison between Preferences of Ordinary Citizens and Administrative and Organisational Officers for Nonconventional Water Resources or Distributed Water Resources Mainly in Urban Area}

\author{
Yoshiaki TSUZUKI ${ }^{*, "}$ and Toshiya ARAMAKI** \\ * Research Centre for Coastal Lagoon Environments, Shimane University, Nishikawatsu 1060, Matsue City, Shimane Prefecture 690-8504, \\ Japan \\ ** Regional Development Studies, Toyo University, Hakusan 2-36-5, Bunkyo-ku, Tokyo 112-0001, Japan
}

\begin{abstract}
Preferences for three nonconventional water resources or distributed water resources mainly in urban area rainwater harvesting $(\mathrm{RH})$, submersible groundwater $(\mathrm{SG})$, and reclaimed wastewater $(\mathrm{RW})$ - and their five usages toilet flushing water (FW), sprinkle water (SW), environmental water (EW), water against disasters (DW), and water for agriculture and planting (AW) - of ordinary citizens and administrative officers were comparatively analysed on the basis of questionnaire survey results obtained by analytical hierarchical process (AHP), absolute evaluation and willingness to pay (WTP) determination. McNemar, average difference, and Welch examinations were used to evaluate the differences in the results. For the second set of criteria in AHP, the administrative officers' preferences were larger for stability (corresponding to 'society' in the first set of criteria, here and throughout), project cost and duration ('economics') and water environment ('nature') than the ordinary citizens' preferences. For water resources, the order of preferences was (1) RH, (2) RW and (3) SG for both administrative officers and ordinary citizens. For water usages, the preferences for DW and AW were comparatively larger than those for other usages. The administrative officers' public WTPs for 15 combinations of water resources and usages, i.e., 4,172-21,572 Japanese Yen person $^{-1}$ year $^{-1}$ (YPY), were mostly larger than the ordinary citizens' public WTP, i.e., 6,152-17,336 YPY. The administrative officers' private WTPs, i.e., 1,106-4,044 YPY, were mostly smaller than the ordinary citizens' private WTP, i.e., 2,561-5,934 YPY.
\end{abstract}

Keywords: Distributed urban water resources; AHP; Absolute evaluation; Statistical examination; WTP

1. はじめに

都市分散型水資源（雨水，地下構造物浸出水，下水処 理再生水) のうち, 雨水, 下水処理再生水は, 例えば, 神田川，寝屋川流域の水循環構想に見られるように活用 事例が増えているが, 地下構造物浸出水の活用事例は限 定的である ${ }^{1,2)}$ 。これらの水資源の名称については，例え ば，国土交通省のパンフレット「都市における未活用水 の利用事例〜都市をうるおす水のみち〜」3)では，水質が 良好で，有効利用されずに下水道や河川などに排水され ている水, 具体的には, 雨水, 湧水, 地下水, 地下構造 物への浸出水，下水再生水，工場排水などを「未活用水」 と総称している。一方，吉野川水系に㧍ける水資源開発 基本計画（吉野川フルプラン）の中間評価書 ${ }^{4)}$ では，「未 利用水」の利用や水需要抑制の強化が検討されている。
以上のことから, 日本では, 従来からの水資源である表 流水, 地下水に加えて, 雨水, 湧水, 地下構造物浸出水, 下水処理再生水等の水源を総称する用語は定まっていな いが，それらの有効性，有用性等について，流域レベル， 地域レベルでの総合的な検討が行われ始めている。

政府が数年ごとに水をテーマにした世論調査を行って いる。平成 20 年 6 月の「水に関する世論調查」5)のテー マは, 水辺の環境, 水道水質の満足度から世界各地で発 生している水問題および水問題解決のための日本の援助 や協力まで幅広い。このうち水辺の環境，水道水源の認 知度, 水道水質の満足度, 雨水·再生水の利用への賛否, 下水道の排出先の認知度, 行政への注文の 5 項目が, 都 市分散型水資源活用に関するテーマと考えられる。雨水・ 再生水の利用については，積極的に使いたいが $28 \%$, 用途に応じた水質であれば使いたいが59\%で合計 $86 \%$

* 島根大学汽水域研究センター協力研究員 † 690-8055 島根県松江市西川津町 1060

** 東洋大学国際地域学部 $\overline{\mathrm{T}} 112-0001$ 東京都文京区白山 2-36-5

ๆ連絡先：tsuzuki.yoshiaki@gmail.com 
であり，あまり使いたくないが $9 \%$ ，使いたくないが $3 \%$ で合計 $12 \%$ であった。

一方，公共事業等における意思決定法としてコンジョ イント分析法，階層分析法（AHP）等を用いた検討が行 われてきた ${ }^{6 \sim 10)}$ 。AHP については学術的側面から様々な メリットが述べられている7)。水資源を対象として AHP を用いて評価を行った先行研究としては, 環境用水によ る河川流量の増加についての評価 ${ }^{11)}$, 水道供給の信頼性 について AHP を活用して評価した研究 ${ }^{12)}$, 水供給シス テム再生手法についての 5 種類のエコデザイン（高度浄 水導入, 都市内水資源活用, 下水処理水の放流先移設, ペットボトルによる飲料水供給(リュース, ワンウェイ)) を対象にパフォーマンス, 環境負荷, コストを評価基準 (要素) として AHP により重み付け評価を行った研究 ${ }^{13)}$ がある。その他の手法による研究としては, 下水処理水 の環境用水としての利用についてコンジョイント分析, CVM を適用した研究 ${ }^{14)}$, 流域水資産健全度指数を用い て水資源の改善策を評価した研究 ${ }^{15)}$ がある。

海外では, アメリカ工兵隊が洪水対策のいくつかの手 法について AHP を用いて評価を行った研究 ${ }^{16)}$, ヨルダ ンに抏いて新しい水資源について AHPを用いて評価を 行い, 海水の淡水化, 雨水利用の評価が高く, 下水の再 利用, 他地域からの水の移入の評価が低いという結果が 得られた研究 ${ }^{17)}$, フィンランドにおいて水資源に関する 複数の関係者による評価のパレート最適解を求める手法 を検討した研究 ${ }^{18}$ 等がある。森林等の自然環境としての 水資源管理手法の分野では, AHP と他の手法を組み合 わせてモデルを構築する研究が行われており, AHP と 森林における種のストック増加 (GSO), 適当な再生方 法（RM）を組み合わせることにより，森林中の水資源 を総合的に評価する空間利用意思決定システム（SDSS） を構築した研究 ${ }^{19)}$, アメリカ水道井戸協会が環境省のた めに開発した井戸水の污染危険度を評価する DRASTIC モデル, AHP および GIS ソフトウェアのArcView を組 み合わせた地下水污染評価システムを構築した研究 ${ }^{20)}$, 地域の水資源の意思決定を目的として多目的解析モデル を計算機上に構築した研究 ${ }^{21}$ 等がある。

水資源に関しては, 最近ではダム問題が注目されてい る他, 渴水, 洪水の問題がある地域もあり, 地域レベル での気候変動の影響も検討されている。これまで筆者ら は, 都市分散型水資源の一般市民等の選好について検討
するための予備的検討等を行ってきた ${ }^{22)}$ 。

本研究においては, サンプル数が 1,000 件を超える AHP の大規模調查結果の解析方法を開発し, 一般市 民と行政等担当者の都市分散型水資源に関する選好を AHP を含むアンケート調査結果の解析により検討する ことを目的とした。アンケート調査は, 一般市民を対象 とするインターネット調査, および行政, 水資源関連企 業, 団体等の担当者（以下，行政等担当者とする）を対 象とする同様の内容の郵送による調査を行い, 両者の選 好の重みベクトルや絶対評価の結果を統計的手法を用い て比較検討することにより, その差の有意性等について 検討した。アンケート調査に先立ち, 政府による関連テー マの世論調査の結果を整理するとともに, 現在の公共事 業等における意思決定論について整理した。

\section{2. 政府の世論調査結果における水問題に関する認識の 動向}

平成 13（2001）, 20（2008）年に行われた政府の水に 関する世論調查 ${ }^{5,23)}$ において, 行政に力を入れて欲しい ことについての回答結果を整理して Table 1 に示す。こ れらの 10 項目について, 水量·水質, 環境改善·竾害対策, 行政主導・市民参加の 3 軸により整理すると Fig. 1, 2 の ようになる。平成 20（2008）年の上位 5 項目は平成 13 (2001) 年 7 月の上位 5 項目と同様であったが, 回答割合, 順位が変化した。上位 5 項目の選択肢中, (2)水辺環境の 保全と整備，(3)水の再利用の促進，(4)水質浄化対策，(5) 下水道等の整備は, 水質, 生態系等と関わる項目で, 相 互に関連している。都市分散型水資源に関わりが深いと 思われる項目は, (3)水の再利用の促進, (7)渇水対策の水 資源開発施設の整備，(8)地下水の保全である。

3. 公共事業等の意思決定法としてのAHP を用いたー 般市民と行政等担当者の選好の比較検討

藤井 ${ }^{6}$ は, 社会的決定の意思決定方式には, Table 2 の 4 種類があるとした。現実社会において，これらが複 合して意思決定が行われている ${ }^{7}$ 。木下・大野 ${ }^{7)}$ は公共 事業等に関する意思決定をテーマとする既存研究を概観 し, AHP とコンジョイント分析を意思決定に用いる手 法について整理した。

決め方についての研究は, 厚生経済学や社会心理学の 分野を中心に行われている ${ }^{7)}$ 。これらの社会心理学的研

Table 1 Japanese government questionnaire survey results of ordinary people's needs on governments' roles on water resources and environment in 2001 and 2008 .

\begin{tabular}{lccc}
\hline What people want to the governments ? & 2001 & 2008 & Increase/decrease \\
\hline (1) Flooding and sand disasters & 50.8 & 53.1 & $+^{\mathrm{a}}$ \\
(2) Water environment conservation & 46.3 & 52.5 & $++^{\mathrm{b}}$ \\
(3) Wastewater reuse & 44.4 & 52.0 & $++^{\mathrm{b}}$ \\
(4) Water quality in the river and lakes & 50.1 & 48.9 & $-{ }^{\mathrm{c}}$ \\
(5) Wastewater treatment plants (WWTPs) & 51.7 & 43.6 & $--^{\mathrm{d}}$ \\
(6) Conservation of water resources & $\mathrm{NA}^{\mathrm{e}}$ & 36.5 & $\mathrm{NA}^{\mathrm{e}}$ \\
(7) Preparing for draught & $\mathrm{NA}^{\mathrm{e}}$ & 35.3 & $\mathrm{NA}^{\mathrm{e}}$ \\
(8) Groundwater preservation & $\mathrm{NA}^{\mathrm{e}}$ & 34.6 & $\mathrm{NA}^{\mathrm{e}}$ \\
(9) Dissemination on water and learning opportunity & $\mathrm{NA}^{\mathrm{e}}$ & 26.2 & $\mathrm{NA}^{\mathrm{e}}$ \\
(10) Conditions for NGO activities & 14.1 & 17.6 & $+^{\mathrm{a}}$ \\
\hline
\end{tabular}

a: Increase up to $5 \%$ points; b: Increase by $5-10 \%$ points; c: Decrease up to $5 \%$ points; d: Decrease by $5-10 \%$ points; e: Not available. 


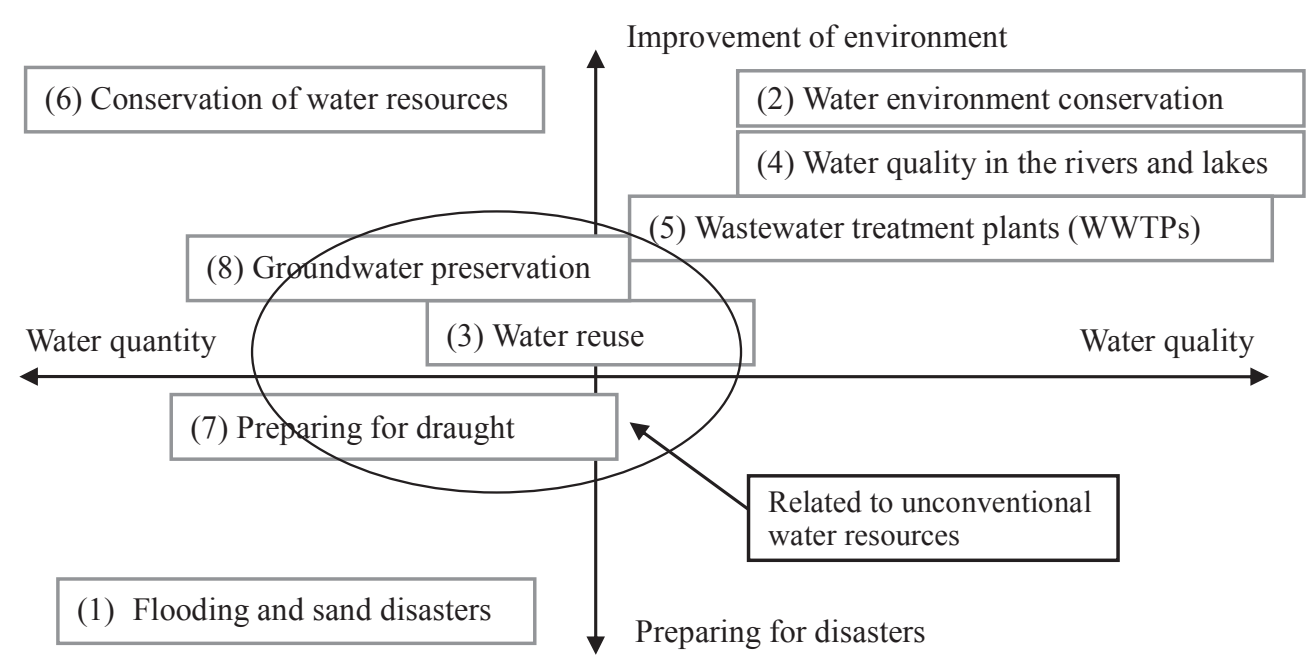

Fig. 1 Water environment related issues summarised with two axes, water quantity - water quality, and environment improvement measurements against disasters.

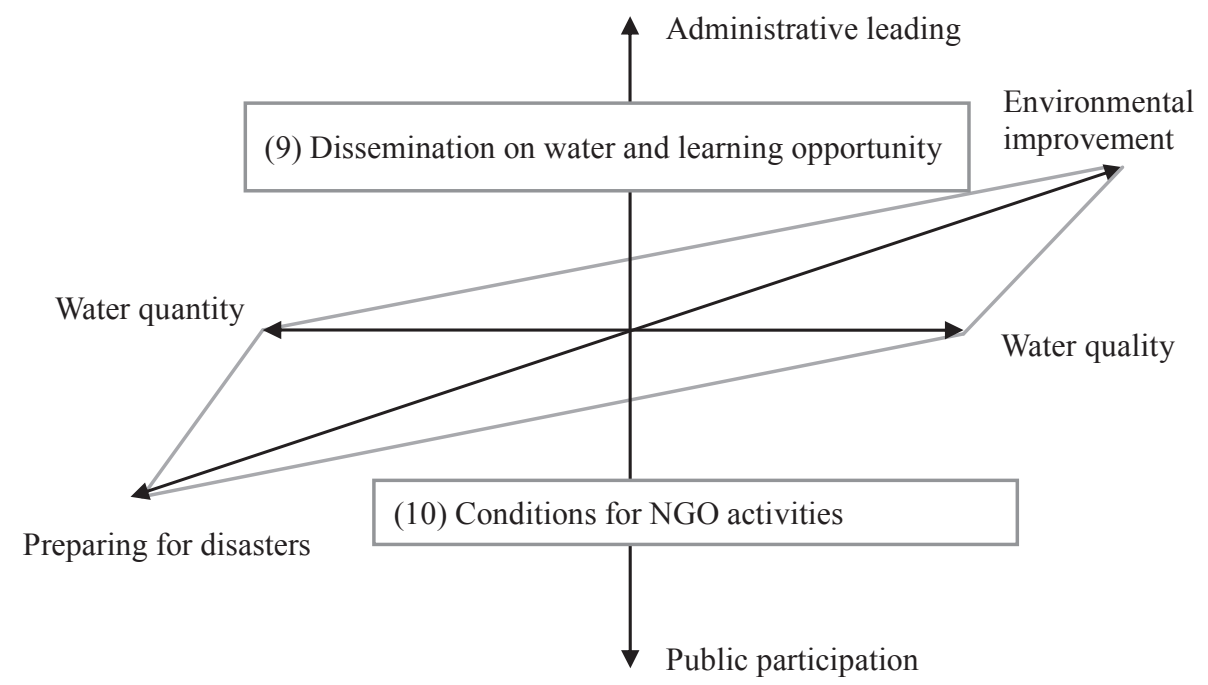

Fig. 2 Water environment related issues summarised with three axes, water quantity - water quality, environment improvement - measurements against disasters, and administrative leading - community involvement.

Table 2 Categorisation of social decision methods (Prepared based on Kinoshita and $\mathrm{Ohno}^{\text {) }}$; Original source is Fujii $\left.{ }^{6}\right)$.

\begin{tabular}{ll}
\hline $\begin{array}{l}\text { Centralised or } \\
\text { democratic }\end{array}$ & Decision method \\
\hline Centralised method & Ruling power \\
\hline Democratic method & Vote \\
& Discussion \\
\hline
\end{tabular}

究等の研究成果の中から, 公共事業等の意思決定につい ては，次のような考え方が提示されてきた6)。

（1）決定の質（社会的厚生の水準）の観点からは，民 主的決定方式による決定が, 社会内の最も優秀な個 人 1 人の決定を下回る事が多い24)。

(2) 常に単一の決定をもたらす投票選好集約（投票に よる多数決方式 ${ }^{6}$ による民主的決定方法は存在し ない 25, 26)。

(3) 議論選好集約方式（話し合い方式 $)^{6)}$ によると, 議論の後の意見分布は, 議論の前の意見分布におけ る多数派が, 上り多数派となる傾向が強い ${ }^{24)}$ 。 (1)の視点は, 本研究について考えると, アンケート調
査により住民選好や市民意識をとりまとめた結果に基づ いて意思決定を行うことの危うさを考えておく必要があ る。アンケート調查結果に基づいて住民選好を把握する ことは, 現代社会においては意思決定についての重要な 要素となるが, 都市分散型水資源の活用のような比較的 なじみが薄い分野では, アンケート調查の意義は, 特に 初期の段階においては, 一般市民への情報提供の要素が 強い。継続的な情報提供やアンケート調查を行うことに より, 今後, 住民選好がどのように変化していくか, 地 域間の相違, 年代間の相違, 提供情報による変化等を検 討するという意義もある。一方, 雨水, 地下構造物浸出水, 下水処理再生水等の都市分散型水資源の活用方法, 打上 びそのメリット，デメリットを整理しておくことが専門 家サイドの重要な役割である。(2)については，様々な状 況の変化や影響を及ぼす情報の変化により，一般市民の 考え方は変化し，木下・大野 ${ }^{7}$ が指摘するように，投票 方式や集約方式を操作することにより, 結果を操作する ことも不可能ではないであろう。(3)については,「話せ ば分かる」という素朴な期待への裏切り ${ }^{7}$ があるとの指 摘である。

公共事業等には費用負担の問題が関連し, 公共的事業 の社会的公正感に関する既存研究の整理により, 公正感 
は，(1)分配的公正と，(2)手続き的公正に分けて考えるこ とができることが示されている7

以上のような公共事業関連の意思決定に関する既存研 究を踏まえると, 本研究で都市分散型水資源についての 一般市民および行政等担当者の選好を AHP を用いて検 討することは，水資源とその活用方法という技術的側面 が大きなテーマについて，一般市民と行政等担当者との 選好の相違点を明らかにするという意味合いを持つ。こ れは, 必ずしも一般市民または行政等担当者の認識のど ちらが正しいのかという観点から検討するものではな く, 科学的に差があるのかどうか, 差があるとするとど のような差があるのか, その差は有意な差であるのか, というような点が本研究の検討対象ということである。

\section{4. 方法}

\section{1 一般を対象としたアンケート調査方法}

評価基準は都筑・荒巻 ${ }^{22)}$ の結果を参考に，第 1 段階 5 項目，第 2 段階 10 項目に变更した（Fig. 3)。代替案は, 都筑 - 荒巻 ${ }^{22)}$ と同様に, 3 水源（雨水, 地下構造物浸出 水, 下水処理再生水), 5 用途（雑用水, 散水, 親水用水, 災害用水, 農業・園芸用水）とした。農業用水は, アメ リカ, イスラエル, 中国等で主要な下水処理再生水の用 途の 1 つとなっており, 日本でも熊本県, 香川県等で活 用されている ${ }^{27 \sim 29) 。 ~}$

アンケート調査は平成 21 (2009) 年 12 月にインターネッ 卜調査の方法で行った。インターネット調査の長所, 短 所については大塚らが整理している ${ }^{10)}$ 。対象地域につい ては, 調查方法の調查地域が限定されないという利便性 を生かし, 6 地方 23 都府県を対象とした。広域を対象と したのは, 本調查においては特定の水域等を対象としな かったので, 都市分散型水資源という比較的新しいテー マであることから, 対象を限定した地域とせず, 最近 10 年間で渴水，洪水等があった地域等の水資源への関心が 比較的大きいと思われる地域を中心に広い地域とする方

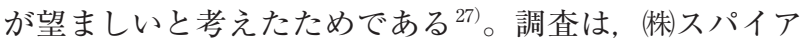
社のモニターを対象に2009年12月2日〜8日に実施した。

代替案（水源と用途）の直接の一対比較（「どちらと も言えない」，2つの選択肢の選考の強さ 4 段階, 「分か
らない」の合計 10 個の選択肢），2段階の評価基準（第 1 段階 5 項目, 第 2 段階 10 項目）に基づく代替案の絶 対評価（100 点満点， 20 点刻み）を設問とし，これらの 結果を用いて代替案の重みべクトルの算定を行った。

さらに, 水源と用途の組合せについて, 評価基準な しの絶対評価，公的および私的 WTP（1 人あたり年額） を質問した。WTP については，平成 20 年度の国の予算 の項目ごとの 1 人あたりの歳出金額のグラフと公共事業 費は 1 人当たり約 5.5 万円であったことを示した上で, 1 年間に公的および私的にどの程度の金額を支出するこ とが望ましいかを質問した。これらの設問は貨幣価值換 算を含む絶対值を得ることにより, AHPの相対評価の 結果を補完することを狙いとした。

集計サンプル数は調査開始時に合計 1,200 サンプルを 想定し, サンプリング時の属性は, 男女別, 年齢区分別 (20７0 代， 6 区分), 地方別 (東北, 関東, 中部, 近畿, 四国, 九州, 6 地方 23 都府県), 都市規模別 (市町村の 人口規模等, 4 区分）の 4 種類とした。調査項目の詳細 はアンケート調査の際に作成したホームページ（http:// www2.toyo.ac.jp/ aramaki/kensetsugijutsu/index.html）を参 照していただきたい。

\section{2 行政等担当者を対象としたアンケート調査}

行政等担当者を対象に郵送によるアンケート調査を平 成 $21 （ 2009 ）$ 年 12 月〜平成 22（2010）年 1 月に行った。 アンケート送付先は, 雨水と下水処理再生水については, 一般市民対象の調査対象地域である 23 都府県から各 5 自治体を選定した。市町村の選定方法は, 都府県, 都府 県庁所在地の 2 自治体と, ランダムに選定したその他の 3 市町村の合計 5 自治体とした。下水処理再生水につい ては, 流域下水道事務所 10 か所を追加した。地下構造物 浸出水については, 主要大都市, 鉄道会社, 電力会社等 の 22 団体を対象とした。アンケート回答用紙等は上記の ホームページ上にも掲載し, ワープロ入力, 電子メール 送付による回答方法も選択可能とした。送付数 312 件に 対して回答数 117 件（回収率 $38 \%$ ）であった。設問の内 容は，(2)の一般市民対象のアンケート調査と同様とした。

4.3 アンケートデータ解析方法

グループの意思決定に関しては, 一対比較值は一対比

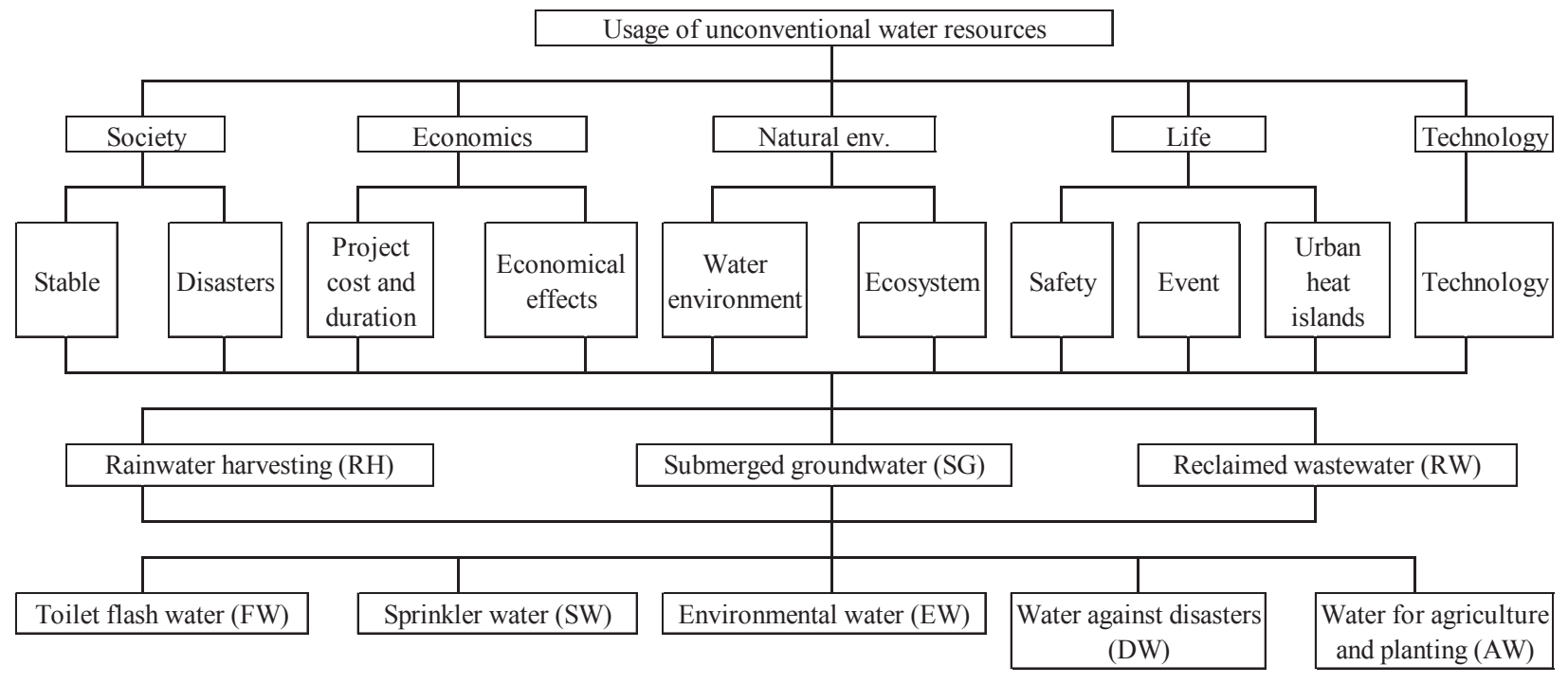

Fig. 3 AHP framework for nonconventional water resources or distributed water resources in urban areas. 
較行列の対角の值は逆数になるという関係があるため, グ ループを構成するメンバーの一対比較值の幾何平均值を 用いるとされている ${ }^{30)}$ 。一方, 椿本 ${ }^{31}$ は Ramanathan and Ganesh $^{32}$ を基に, AHP の計算において，グループの意思 決定を統合する手法として用いられている幾何平均法が 社会的選択公理を満たさない場合, 特にパレート最適の公 理を満たさない場合があることを示した。さらに，加重算 術平均法が「無関係な代替案からの独立性の公理」以外 の社会的選択公理を満たすことを示し, 加重算術平均法 により各メンバーの意見の重要度を求める方法を示した。

本研究では, グループの重みベクトル算定方法とし て, 各サンプルの重みを均一とした加重算術平均法を用 いた。重みべクトル間および WTPを含む絶対評価間の 差の有意差については, 平均值の差の検定, McNemar の検定, Welchの検定を行った。Welch 検定等の二群の 平均值等について検定を行う場合には, それぞれの群の 正規分布，等分散についての検定を行い，検定方法を選 択することとされているが，Kasuya ${ }^{33)}$ ，青木 ${ }^{34)}$ は，等 分散ではない場合には中央值検定と言うょりも，「順序 尺度の場合には中央值検定, 間隔尺度 - 比尺度の場合に は等分散を仮定しない $\mathrm{t}$ 検定, あるいは等分散検定後に 普通の $\mathrm{t}$ 検定」を用いることが望ましいとしている。青 木 ${ }^{34)}$ は, 「等分散を仮定しない $\mathrm{t}$ 検定 (Welch 検定) 」は, 「標 準偏差の比 $1 / 4 \sim 4$ の全て」,「サンプルサイズのアンバ ランスな全て」,「データの分布型の全て」の条件で,「第 一種の過誤が 0.05 にキープされていること」を示した。 本研究では, 正規検定, 等分散検定に関わらず, Welch 検定を用いた。

\section{AHP における検定方法についての検討結果}

一般を対象とした調査結果について第 1 段階の評価基 準に基づく水源の重みべクトルを Fig. 4 に示す。5つの 評価基準のうち, 社会, 経済, 自然環境, 生活の 4 つで は 3 水源の重みベクトルの大きさが雨水, 下水処理再生 水, 地下構造物浸出水の順となり, 技術では下水処理再 生水, 雨水, 地下構造物浸出水の順となった。

これらの重みベクトル間の差についての有意性を検
討するために行った平均值の差の検定結果を Table 3 に, McNemar 検定の結果を Table 4 に示す。Table 3 に は McNemar 検定の 5 区分について, 有意水準 1\%で差 がある場合を 2 点, 有意水準 $5 \%$ で差がある場合を 1 点 とした場合の合計の点数（10 点満点）を併記した。平 均值の差の検定では，ほとんどの水源間で有意水準 $1 \%$ で差があるという判定結果となり，技術を評価基準とし たときの雨水と下水処理再生水の平均值の差の有意水 準のみが5\%であった。これに対して, McNemar 検定 は, どの点数区分で差があるかを判定することができる。 McNemar の検定結果を点数化することにより, 平均值 の差の検定で有意水準 $1 \%$ で差があると判定された代替 案間の差の有無について, 追加的な判定を行う手法を新 たに導入した。例えば, 生活を判断基準とした地下構造 物浸出水と下水処理再生水の重みべクトルの平均值は有 意水準 $1 \%$ で差があると判定されたが, McNemar 検定 の点数化では 10 点満点中 2 点であることから, 比較的 差が小さいと判断することができた。

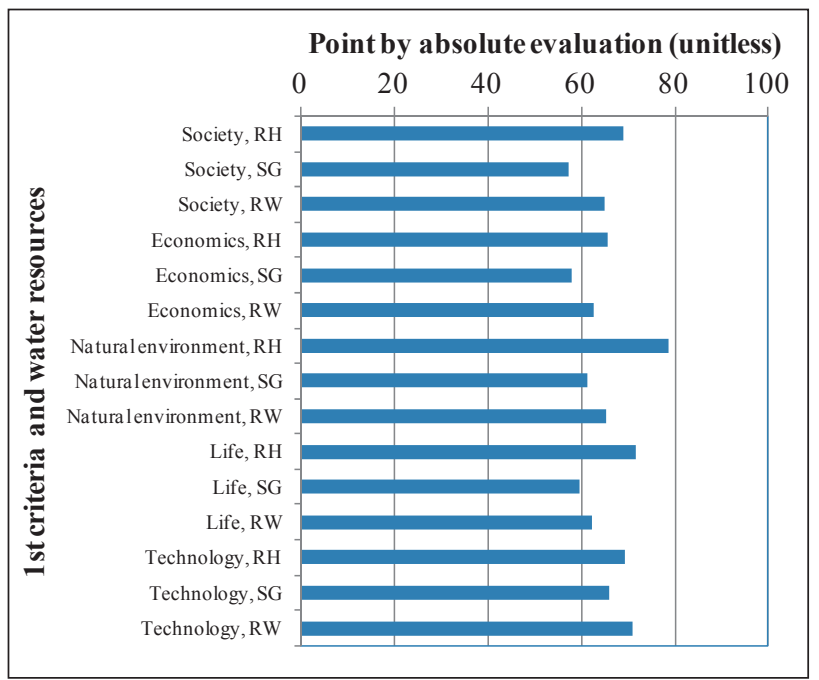

Fig. 4 Weight vectors of water resources by ordinary citizens based on the first criteria.

Table 3 Examination results of average differences between water resources weight vectors based on the first evaluation criteria by ordinary citizens.

\begin{tabular}{|c|c|c|c|c|c|c|c|c|}
\hline First criteria & $\begin{array}{l}\text { Combination of } \\
\text { water resources }\end{array}$ & $\begin{array}{l}\text { Average of } \\
\text { difference }\end{array}$ & $\begin{array}{l}\text { Standard deviatior } \\
\text { of difference }\end{array}$ & $\begin{array}{c}\text { The number of } \\
\text { samples }\end{array}$ & $\mathrm{T}_{\text {value }}^{\mathrm{a}}$ & & f value. & $\begin{array}{l}\text { Point of } \mathrm{M} \\
\text { examination }\end{array}$ \\
\hline \multirow{3}{*}{ Social } & RH \& SG & 11.50 & 24.55 & 1,050 & 15.185 & $* *$ & 1,049 & 8 \\
\hline & RH \& RW & 3.86 & 25.73 & 1,092 & 4.962 & $* *$ & 1,091 & 6 \\
\hline & SG \& RW & -7.84 & 24.06 & 1,043 & -10.525 & $* *$ & 1,042 & 8 \\
\hline \multirow[t]{3}{*}{ Economics } & $\mathrm{RH} \& \mathrm{SG}$ & 7.41 & 25.32 & 1,028 & 9.387 & $* *$ & 1,027 & 6 \\
\hline & RH \& RW & 2.92 & 27.50 & 1,068 & 3.472 & $* *$ & 1,067 & 5 \\
\hline & SG \& RW & -4.56 & 22.87 & 1,021 & -6.377 & $* *$ & 1,020 & 7 \\
\hline \multirow{3}{*}{$\begin{array}{l}\text { Natural } \\
\text { environment }\end{array}$} & RH \& SG & 16.97 & 25.03 & 1,061 & 22.075 & $* *$ & 1,060 & 8 \\
\hline & RH \& RW & 13.34 & 25.64 & 1,099 & 17.249 & $* *$ & 1,098 & 6 \\
\hline & SG \& RW & -3.66 & 23.59 & 1,045 & -5.010 & $* *$ & 1,044 & 6 \\
\hline \multirow[t]{3}{*}{ Life } & $\mathrm{RH} \& \mathrm{SG}$ & 11.69 & 25.09 & 1,052 & 15.117 & $* *$ & 1,051 & 8 \\
\hline & RH \& RW & 9.13 & 26.72 & 1,102 & 11.341 & $* *$ & 1,101 & 8 \\
\hline & SG \& RW & -2.66 & 24.27 & 1,046 & -3.542 & $* *$ & 1,045 & 2 \\
\hline \multirow[t]{3}{*}{ Technology } & RH \& SG & 3.30 & 26.08 & 1,043 & 4.084 & $* *$ & 1,042 & 2 \\
\hline & RH \& RW & -1.63 & 26.71 & 1,065 & -1.996 & $*$ & 1,064 & 3 \\
\hline & SG \& RW & -4.98 & 20.79 & 1,040 & -7.727 & $* *$ & 1,039 & 7 \\
\hline
\end{tabular}

a: **: significant at $1 \%$, and $*$ : significant at $5 \%$; b: Total significance of Mcnemar examination results in five categories is evaluated with total points of point 2 for $1 \%$ significant and point 1 for $5 \%$ signifincant. 


\section{6. アンケート調査結果と考察}

\section{1 一般と行政等担当者の属性の比較}

一般を対象とするインターネット調査では，ほぼ当初 想定していたサンプルを収集することができた。サンプ ル数が他に比べて少なかった属性区分は，年齢別の 20 代，70 代以上，都市規模別の町村であった。一般と行 政等担当者のアンケート回答の総サンプル数と属性の構 成比を Table 5 に示す。地方の構成比は比較的似ている が, 性別, 年齢区分, 都市規模については両者に違いが 見られた。

\section{2 一般と行政等担当者の選好の比較}

一般と行政等担当者の評価基準の一対比較により求め た重みべクトルを Fig. 5 に示す。一般と行政等担当者間 で差が比較的大きかった第 2 段階の評価基準は, 次のと おりである。行政等担当者の方が大きかったのは，安定
性（対応する第 1 段階の評価基準は，社会。行政等担当 者：0.096, 一般：0.081。以下，同様とする。), 事業費 用および期間（経済。行政等担当者:0.093, 一般:0.062), 水環境（自然環境。行政等担当者: 0.131 ,一般: 0.120 ), 一般の方が大きかったのは, 安全性（生活。行政等担当 者：0.113, 一般：0.124）と都市ヒートアイランドの緩 和（生活。行政等担当者:0.073, 一般:0.087), 技術（技 術。行政等担当者：0.140,一般：0.164）であった。

3 水源, 5 用途の単純な直接の一対比較の結果, 行政 等担当者の方が，水源は雨水の評価が大きく，用途は雑 用水と災害用水の評価が大きく, 親水用水, 農業 - 園芸 用水の評価が小さかった $($ Fig. 6)。

第 1 段階, 第 2 段階の評価基準と代替案（水源および 用途）の絶対評価の組み合わせにより算定した各代替案 の重みベクトルの大きさは, 行政等担当者の重みベクト ルの方が一般に比べて，全体的に小さかった（Fig. 7)。

Table 4 McNemar examination results of water resources' weight vectors based on the first criteria by ordinary citizens.

\begin{tabular}{|c|c|c|c|c|c|c|c|c|c|c|}
\hline \multirow{2}{*}{$\begin{array}{l}\mathrm{T} \text { value of Mcnemar } \\
\text { examination: First criteria }\end{array}$} & \multicolumn{3}{|l|}{ Social } & \multicolumn{4}{|l|}{ Economics } & \multicolumn{3}{|c|}{ Natural environment } \\
\hline & $\mathrm{RH}-\mathrm{SG}^{\mathrm{a}}$ & $\mathrm{RH}-\mathrm{RW} \mathrm{W}^{\mathrm{b}}$ & $\mathrm{SG}-\mathrm{RW}^{\mathrm{c}}$ & $\mathrm{RH}-\mathrm{SG}^{\mathrm{a}}$ & $\mathrm{RH}-\mathrm{R} \mathrm{W}^{\mathrm{b}}$ & $\mathrm{SG}-\mathrm{RW}^{\mathrm{c}}$ & & $\mathrm{RH}-\mathrm{SG}^{\mathrm{a}}$ & $\mathrm{RH}-\mathrm{RW}^{\mathrm{b}}$ & $\mathrm{SG}-\mathrm{RW}^{\mathrm{c}}$ \\
\hline 0 and $\geq 20$ points & 1.2 & 0.0 & 0.8 & 1.6 & 1.1 & $5.8 *$ & & $15.1 * *$ & 0.4 & $9.4 *$ \\
\hline$\leq 20$ and $\geq 40$ points & $53.4 * *$ & $5.0 *$ & $30.2 * *$ & 3.6 & 0.2 & 2.1 & & $65.9 * *$ & $43.2 * *$ & 3.5 \\
\hline$\leq 40$ and $\geq 60$ points & $73.5 * *$ & $5.2 *$ & $43.2 * *$ & $32.1 * *$ & $4.7 *$ & $11.0^{*}$ & $* *$ & $164.9 * *$ & $101.6^{* *}$ & $8.1 *$ \\
\hline$\leq 60$ and $\geq 80$ points & $184.6 * *$ & $24.8 * *$ & $75.8 * *$ & $96.6 * *$ & $12.8 * *$ & 48.3 & $* *$ & 0.1 & 1.2 & 0.6 \\
\hline$\leq 80$ and 100 points & $94.3 * *$ & $22.3 * *$ & $30.3 * *$ & $60.0 * *$ & $12.9^{* *}$ & $24.5 *$ & $* *$ & $249.4 * *$ & $161.1 * *$ & $24.8 *$ \\
\hline \multirow{2}{*}{$\begin{array}{l}\mathrm{T} \text { value of Mcnemar } \\
\text { examination: First criteria }\end{array}$} & Life & & & Technology & & & & & & \\
\hline & $\mathrm{RH}-\mathrm{SG}^{\mathrm{a}}$ & $\mathrm{RH}-\mathrm{RW} \mathrm{W}^{\mathrm{b}}$ & $\mathrm{SG}-\mathrm{RW}^{\mathrm{c}}$ & $\mathrm{RH}-\mathrm{SG}^{\mathrm{a}}$ & $\mathrm{RH}-\mathrm{RW} \mathrm{W}^{\mathrm{b}}$ & $\mathrm{SG}-\mathrm{RW}^{\mathrm{c}}$ & & & & \\
\hline 0 and $\geq 20$ points & $14.1 * *$ & $7.6 * *$ & 1.0 & 0.2 & 0.6 & 2.4 & & & & \\
\hline$\leq 20$ and $\geq 40$ points & $30.1 * *$ & $21.3 * *$ & 0.5 & 0.1 & 2.6 & $5.1 *$ & $*$ & & & \\
\hline$\leq 40$ and $\geq 60$ points & $77.0 * *$ & $45.3 * *$ & $4.1 *$ & 1.0 & $4.0 *$ & $13.8 *$ & $* *$ & & & \\
\hline$\leq 60$ and $\geq 80$ points & 1.0 & 2.1 & 0.3 & 0.1 & $47.2 * *$ & $45.9 *$ & $* *$ & & & \\
\hline$\leq 80$ and 100 points & $133.4 * *$ & $93.9 * *$ & $6.5 *$ & $36.6 * *$ & 0.0 & $46.9 *$ & $* *$ & & & \\
\hline
\end{tabular}

Table 5 Total numbers of samples and constituent percentages in questionnaire surveys to ordinary citizens and administrative and organisational officers.

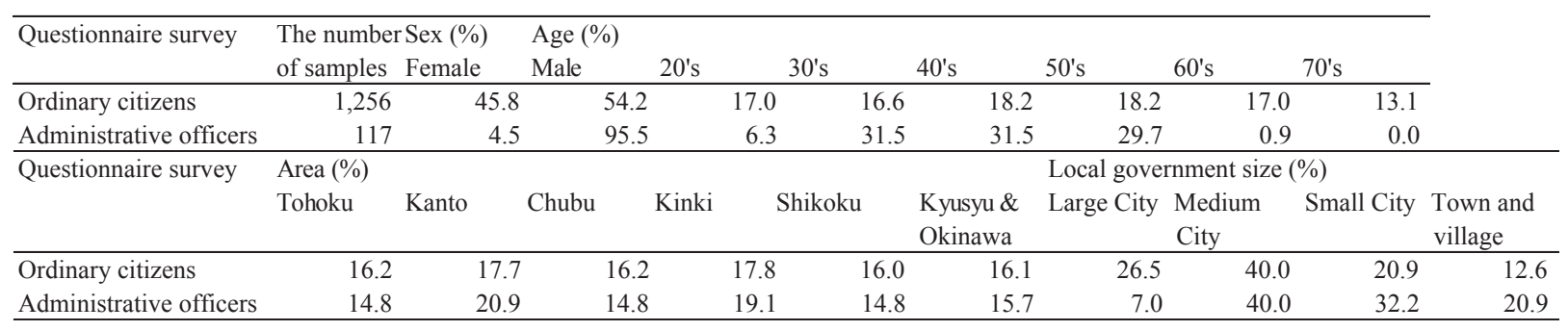
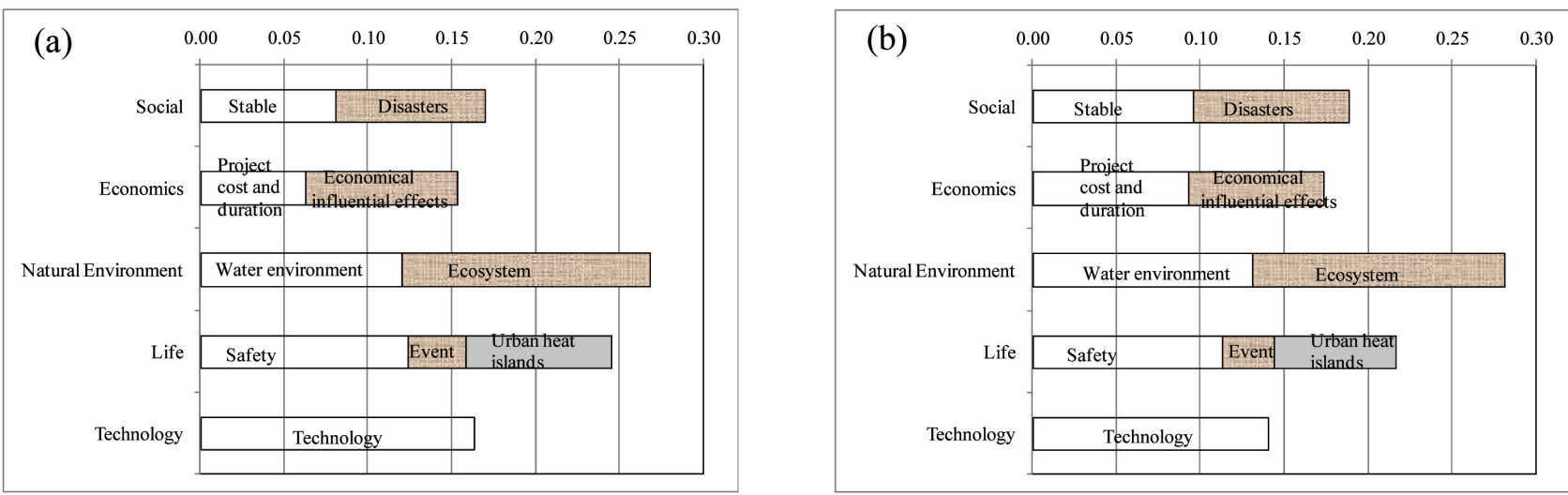

Fig. 5 Weight vectors of the evaluation criteria by (a) ordinary citizens and (b) administrative and organisational officers. 
Fig. 6 と Fig. 7 を比較すると, 直接の一対比較では 行政等担当者の雨水の評価は一般よりも大きかったが (Fig. 6)，AHPの手法を用いた評価基準に基づく評価は, 3 水源とも一般の重みべクトルが大きかった（Fig. 7)。 Fig. 7 で 3 水源とも一般の重みべクトルの方が大きかっ たのは,この結果が評価基準と絶対評価の組み合わせに 基づくものであったことが原因の 1 つとなっている。 3 水源の重みべクトルの合計值が 1 となるような相対值で 比較すると, Fig. 6 と Fig. 7 の傾向は同様となり, 行政 等担当者の雨水の評価が相対的に大きくなった。れは, 雨水利用については, 他の 2 水源に比較して全国的に普 及が進められてきていることを反映しているものである と考えられる。

行政等担当者による用途の重みベクトルの相対的な順 番は，第 1 段階の評価基準を用いた場合には親水用水の 重みベクトルが一般に比べて小さかったが，第 2 段階の 評価基準を用いた場合には一般と同様で, 両者とも災害
用水，農業・園芸用水が比較的大きかった。

以上のような一般と行政等担当者の水源と用途につい ての選好の差の原因については, 現在のところは仮説の 段階であるが, 次のように考えられる。行政等担当者の 選好には, 水源, 用途についての現在の日本の国レベル の政策およびそれに基づく行政等担当者の認識が反映さ れていると考えるのは素直な考え方であろう。一方で, 一般市民の選好は国レベルの政策に加えて, マスコミ等 の情報, アンケート調査時の資料等の影響が比較的大き いということを仮説として考えられるだろう。ここでの 視点は, どちらかがより正しいかではなく, 民主主義を 前提として考えると, 行政等担当者および一般市民の選 好間の乘離が小さい方が望ましいと考えられるので, 本 調査結果のように両者の選好に乘離が見られるような場 合には，行政側から一般市民側への情報提供，パブリッ クコメントの有効活用等により, 双方向の情報の流れを 円滑化し, 選好の差を少なくしていくことが安定した水

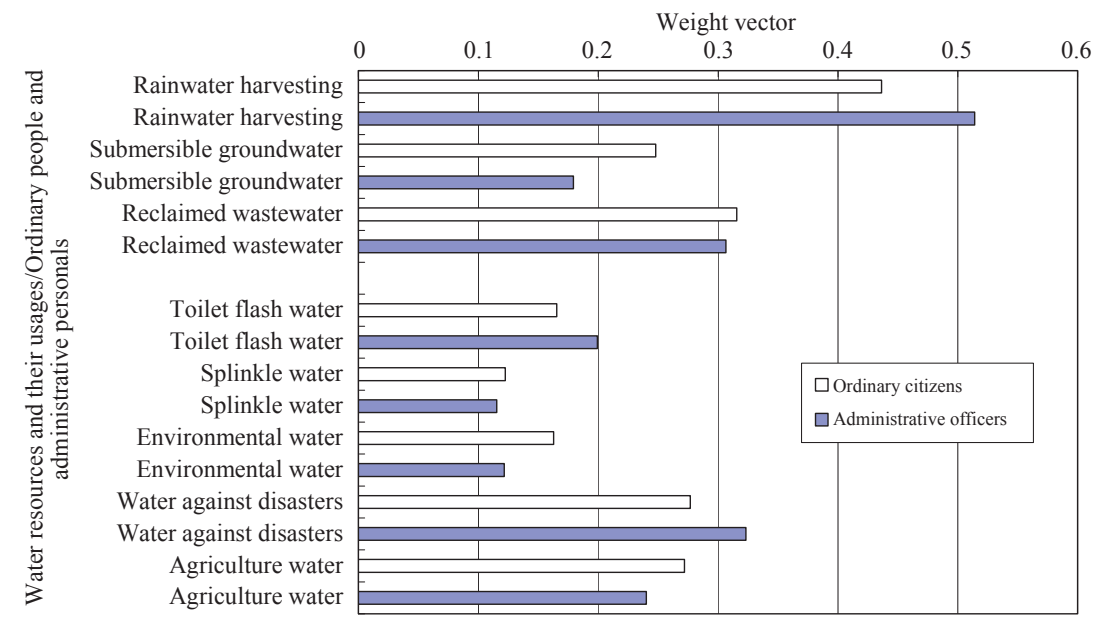

Fig. 6 Weight vector of water resources and their usages determined based on the answers to direct comparison questions.
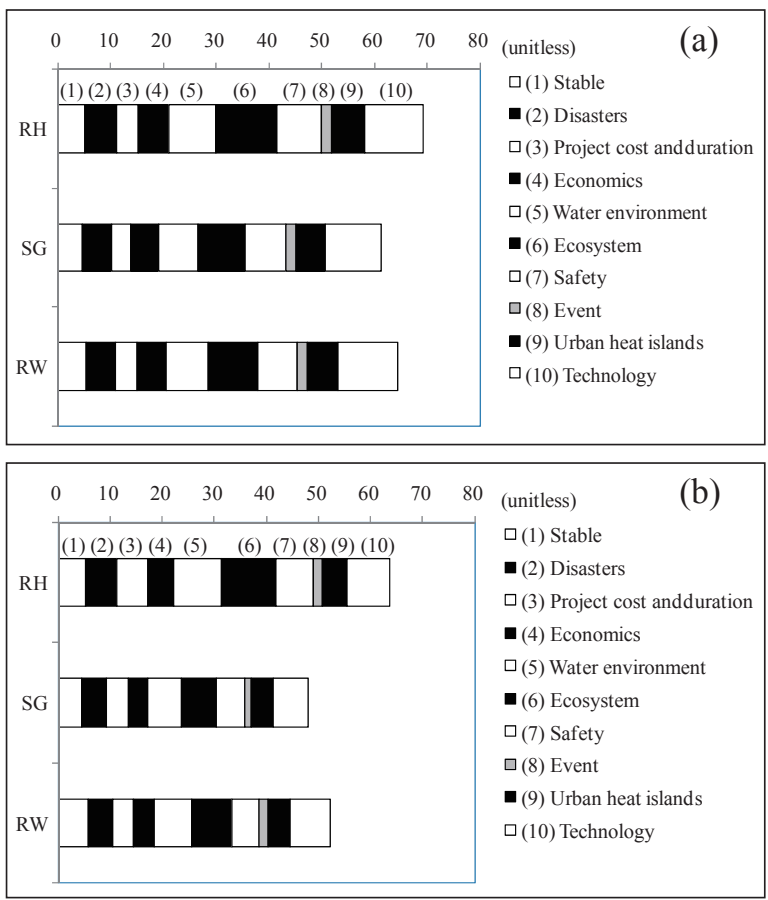

Fig. 7 Water resources' weight vectors based on secondary evaluation criteria for (a) ordinary citizens and (b) administrative and organisational officers.
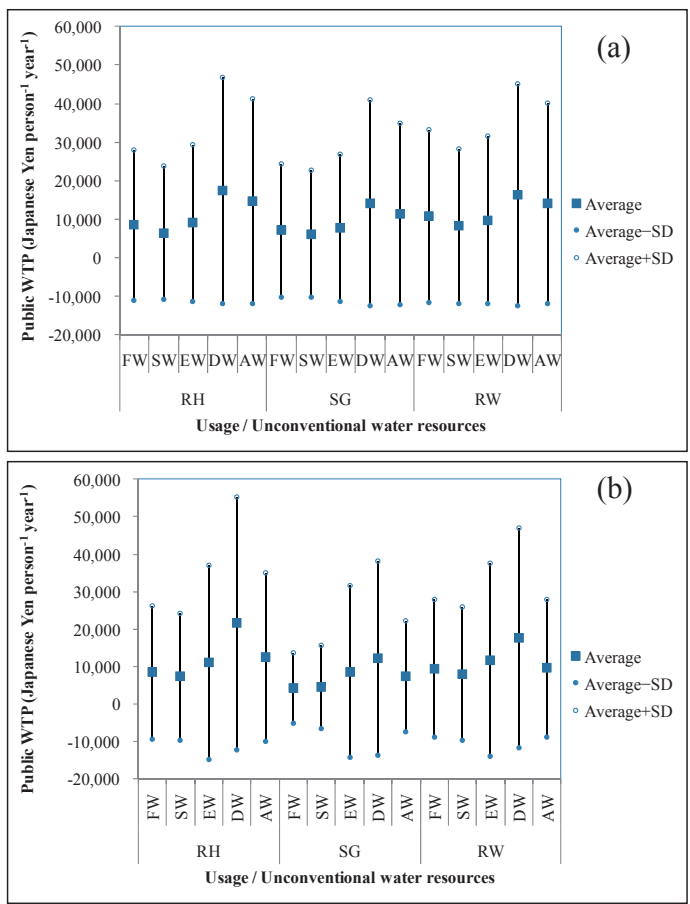

Fig. 8 Public WTP on combinations of water resources and usages for (a) ordinary citizens and (b) administrative and organisational officers (Japanese Yen per persons per year). 
資源行政を進めるための課題であると言えるだろう。そ うであれば，本研究のようなアンケート調査の結果につ いても, 適宜, 回答者を含む一般市民や行政等担当者に 対して, フィードバックしておくことが良好なコミュニ ケーションを図るために望ましい。

水源と用途の組み合わせの絶対評価は, 行政等担当者 の值が一般よりも大きかったのは雨水と雑排水，下水処 理再生水と雑排水の 2 組であった。行政等担当者の公的 WTP が一般の公的 WTP よりも大きかったのは, 雨水と 散水, 親水用水, 災害用水, 下水処理再生水と親水用水, 災害用水の組み合わせで，農業・園芸用水は小さかった (Fig. 8)。一方，行政等担当者の私的 WTP は, 雨水と散 水の組み合わせ以外は一般の私的 WTPよりも小さく, 雑用水は各水源で最大で, 親水用水, 災害用水は小さかっ た。AHPのみの結果に比べて ${ }^{22)}$, 具体的な金銭価值の 尺度のイメージを持つことができる調査結果となった。 WTP は一般，行政等担当者ともばらつきが大きく，（平 均值－標準偏差）の值は負の值となることが多かった。 なお，本研究で得られた一般と行政等担当者との選好の 相違点については，両者の属性の相違による影響を受け ている可能性もあり, この点については今後の検討課題 としたい。

\section{3 水源と用途の組み合わせについての絶対評価, WTP の Welch 検定}

水源と用途の組み合わせについての絶対評価, WTP について，一般と行政等担当者との差の有意性をWelch
検定により検討した（Table 6, 7,8)。なお，例えば，サ ンプルの分布の正規性については, 絶対評価については, 一般は点数が大きい方に分布が偏り正規性が見られず, 行政等担当者は正規分布に近い分布を示したというよう な傾向が見られた。

水源と用途の組み合わせの絶対評価については, 全体 的に行政等担当者による評価の絶対值が一般の評価の絶 対值よりも小さかったという結果の意味については, 判 断が難しい（Table 6)。単純に有意差の検定結果を見る と, 親水用水, 災害用水, 農業・園芸用水は 3 種類の水 源とも行政等担当者と一般の間に有意な差があると判定 された（雨水と親水用水のみ有意水準 $5 \%$, その他は有 意水準 1\%)。雑用水は 3 種類の水源とも有意水準 5\%で 差があると判定された。散水は, 下水処理再生水との組 み合わせは有意水準 $5 \%$ で差があると判定され, 雨水と 地下構造物浸出水との組み合わせでは有意水準 $5 \%$ で差 がないと判定された。

公的 WTP については,多くの組み合わせで有意水準 5\% で差がないと判定された（Table 7)。有意水準 5\%で差が あると判定されたのは, 地下構造物浸出水と雑用水, 農業. 園芸用水, 下水処理再生水と農業・園芸用水の組合せで, いずれも行政等担当者の公的 WTP の方が小さかった。

私的 WTP については, 水源と用途の組合せの絶対評 価と同様に, 全体的に行政等担当者による評価の絶対值 が一般の評価の絶対值よりも小さいという傾向が見られ た (Table 8)。

Table 6 Welch examination results on differences of absolute evaluations for 15 combinations of water resources and usages between ordinary citizens and administrative and organisational officers.

\begin{tabular}{|c|c|c|c|c|c|c|c|c|c|c|c|c|c|c|c|c|c|}
\hline \multirow{2}{*}{\multicolumn{2}{|c|}{ Absolute value evaluation }} & \multicolumn{5}{|l|}{$\mathrm{RH}$} & \multicolumn{6}{|l|}{ SG } & \multicolumn{5}{|l|}{ RW } \\
\hline & & $\mathrm{FW}$ & SW & EW & DW & $\mathrm{AW}$ & $\mathrm{FW}$ & SW & EW & DW & & $\mathrm{AW}$ & $\mathrm{FW}$ & SW & EW & DW & $\mathrm{AW}$ \\
\hline \multirow[t]{3}{*}{ Administrative officers } & Mean & 62.0 & 63.4 & 57.4 & 59.6 & 64.2 & 53.0 & 54.3 & 49.3 & 52.0 & & 47.6 & 57.9 & 54.5 & 46.4 & 49.2 & 49.0 \\
\hline & $\mathrm{SD}^{\mathrm{a}}$ & 27.0 & 28.1 & 27.4 & 28.3 & 24.9 & 25.5 & 26.8 & 26.3 & 25.9 & & 26.5 & 28.4 & 26.3 & 26.9 & 27.1 & 25.9 \\
\hline & Samples ${ }^{\mathrm{b}}$ & 92 & 94 & 93 & 94 & 95 & 83 & 84 & 82 & 83 & & 84 & 95 & 94 & 94 & 93 & 96 \\
\hline \multirow[t]{3}{*}{ Ordinary citizens } & Mean & 67.7 & 68.1 & 66.2 & 69.7 & 75.6 & 59.6 & 58.4 & 58.0 & 63.5 & & 61.4 & 66.0 & 62.3 & 55.2 & 62.9 & 63.0 \\
\hline & $\mathrm{SD}^{\mathrm{a}}$ & 25.2 & 25.8 & 25.3 & 25.6 & 23.9 & 26.7 & 28.1 & 27.3 & 26.3 & & 27.4 & 26.1 & 28.0 & 27.7 & 27.4 & 27.6 \\
\hline & Samples ${ }^{\mathrm{b}}$ & 1,091 & 1,100 & 1,076 & 1,088 & 1,103 & 1,032 & 1,044 & 1,030 & 1,040 & & 1,042 & 1,088 & 1,088 & 1,058 & 1,071 & 1,085 \\
\hline T value & & $-1.974 *$ & -1.581 & $-2.987 * *$ & $-3.369 * *$ & -4.288 & $* *-2.264 *$ & -1.352 & -2.876 & $* *-3.880$ & $* *$ & -4.567 ** & $-2.680 * *$ & $-2.748 * *$ & $-3.023 * *$ & $-4.640 *$ & $-5.052 * *$ \\
\hline f value & & 105 & 107 & 106 & 107 & 109 & 97 & 98 & 95 & 96 & & 98 & 108 & 112 & 111 & 109 & 115 \\
\hline
\end{tabular}

Table 7 Welch examination results on differences of public WTP for 15 combinations of water resources and usages between ordinary citizens and administrative and organisational officers (Japanese Yen person ${ }^{-1}$ year $^{-1}$ ).

\begin{tabular}{|c|c|c|c|c|c|c|c|c|c|c|c|c|c|c|c|c|}
\hline \multirow[t]{2}{*}{ Public WTC } & & \multicolumn{5}{|l|}{ RH } & \multicolumn{5}{|l|}{ SG } & \multicolumn{5}{|l|}{$\mathrm{RW}$} \\
\hline & & $\mathrm{FW}$ & SW & EW & DW & $\mathrm{AW}$ & FW & SW & EW & DW & $\mathrm{AW}$ & $\mathrm{FW}$ & SW & EW & DW & $\mathrm{AW}$ \\
\hline \multirow[t]{3}{*}{ Administrative officers } & Mean & 8403 & 7270 & 11113 & 21574 & 12540 & 4172 & 4534 & 8667 & 12228 & 7431 & 9492 & 8063 & 11806 & 17661 & 9587 \\
\hline & $\mathrm{SD}^{\mathrm{a}}$ & 17853 & 16962 & 25834 & 33770 & 22570 & 9349 & 11082 & 22828 & 26020 & 14902 & 18370 & 17781 & 25655 & 29246 & 18362 \\
\hline & Samples & 62 & 63 & 62 & 61 & 63 & 58 & 58 & 57 & 57 & 58 & 63 & 63 & 62 & 62 & 63 \\
\hline \multirow[t]{3}{*}{ Ordinary citizens } & Mean & 8558 & 6534 & 9044 & 17366 & 14704 & 7163 & 6152 & 7820 & 14214 & 11484 & 10897 & 8230 & 9809 & 16351 & 14159 \\
\hline & $\mathrm{SD}^{\mathrm{a}}$ & 19528 & 17387 & 20273 & 29364 & 26702 & 17332 & 16448 & 19047 & 26674 & 23564 & 22488 & 19992 & 21666 & 28708 & 26136 \\
\hline & Samples ${ }^{\mathrm{b}}$ & 917 & 923 & 903 & 934 & 937 & 876 & 879 & 870 & 883 & 885 & 924 & 916 & 896 & 921 & 916 \\
\hline T value ${ }^{c}$ & & -0.066 & 0.333 & 0.618 & 0.950 & -0.728 & $-2.199 *$ & -1.039 & 0.274 & -0.558 & $-1.920 *$ & -0.578 & -0.071 & 0.598 & 0.342 & $-1.852 *$ \\
\hline f value & & 71 & 71 & 66 & 66 & 74 & 86 & 75 & 61 & 64 & 77 & 75 & 73 & 67 & 69 & 80 \\
\hline
\end{tabular}

Table 8 Welch examination results on differences of private WTP for 15 combinations of water resources and usages between ordinary citizens and administrative and organisational officers (Japanese Yen person ${ }^{-1}$ year $^{-1}$ ).

\begin{tabular}{|c|c|c|c|c|c|c|c|c|c|c|c|c|c|c|c|c|}
\hline \multirow{2}{*}{ Private WTP } & & \multicolumn{5}{|l|}{$\mathrm{RH}$} & \multicolumn{5}{|l|}{ SG } & \multicolumn{5}{|l|}{ RW } \\
\hline & & $\mathrm{FW}$ & SW & EW & DW & $\mathrm{AW}$ & $\mathrm{FW}$ & SW & EW & DW & $\mathrm{AW}$ & $\mathrm{FW}$ & SW & EW & DW & $\mathrm{AW}$ \\
\hline \multirow[t]{3}{*}{ Administrative officers } & s Mean & 4044 & 2943 & 1304 & 2507 & 2377 & 2455 & 1682 & 1106 & 1864 & 1333 & 2914 & 1743 & 1171 & 2214 & 1686 \\
\hline & $\mathrm{SD}^{\mathrm{a}}$ & 8727 & 8546 & 2493 & 3252 & 3396 & 6661 & 6414 & 2425 & 3073 & 2830 & 6593 & 6289 & 2395 & 3257 & 2947 \\
\hline & Samples ${ }^{\mathrm{b}}$ & 68 & 70 & 69 & 69 & 69 & 66 & 66 & 66 & 66 & 66 & 70 & 70 & 70 & 70 & 70 \\
\hline \multirow[t]{3}{*}{ Ordinary citizens } & Mean & 3619 & 2989 & 3467 & 5838 & 5119 & 2953 & 2561 & 3006 & 4682 & 4200 & 4172 & 3198 & 4068 & 5934 & 5046 \\
\hline & $\mathrm{SD}^{\mathrm{a}}$ & 11864 & 11074 & 11835 & 16467 & 15178 & 10727 & 9988 & 11254 & 14850 & 14341 & 13198 & 11537 & 13596 & 16654 & 15511 \\
\hline & Samples ${ }^{\mathrm{b}}$ & 1,030 & 1,034 & 1,019 & 1,029 & 1,026 & 979 & 980 & 979 & 977 & 985 & 1,010 & 1,005 & 1,003 & 1,011 & 1,013 \\
\hline T value & & 0.379 & -0.043 & $-4.534 * *$ & $-5.159 * *$ & $-4.382 * *$ & -0.561 & -1.033 & -4.065 & $* *-4.640$ & ** -4.989 & $* *-1.412$ & $-1.742 *$ & $-5.613 * *$ & $-5.700 * *$ & $-5.589 *$ \\
\hline f value & & 84 & 86 & 375 & 421 & 333 & 90 & 88 & 343 & 370 & 402 & 112 & 105 & 540 & 445 & 469 \\
\hline
\end{tabular}


以上のような，一般市民と行政等担当者との差につい て，現段階では仮説として，その原因を次のように考え た。一部の水源と用途の組み合わせについて行政等担当 者の公的 WTP が一般市民の公的 WTP を有意に下回っ たのは (Table 7), 水資源に関する国レベルの動向に大 きく左右されるところがあることを反映している。公 的 WTP の行政等担当者と一般市民の差が全体的に小さ かったのは, 都市分散型水資源のような比較的なじみが 薄いテーマについて, 両者が税金の必要負担金額をほぼ 同様と考えている。下水処理再生水と農業・園芸用水の 組み合わせについての公的 WTP が大きかったのは, 諸 外国に事例が多く，日本でも一部の地域で進められてい ることについて, 説明資料に記載していたことを, 一般 市民が重要と評価している。これに対して, 行政等担 当者は日本全体ではあまり進められていないので公的 WTP 小さく評価している。また, 地下構造物浸出水 の行政等担当者による評価が比較的小さかったのは, 該 当地域が限定される水源なので, 広域を対象とした今回 の調査では, 実際の地域条件を反映した回答を行ったた めである。

さらに，私的WTP の一般市民と行政等担当者の差の 傾向は, 水源と用途の組合せの絶対評価の結果に類似 していたため, 私的 WTP は絶対評価を反映していたと 判断できる（Tables 6, 8)。親水用水, 災害用水, 農業 · 園芸用水については, いずれの水源との組み合わせも行 政等担当者による絶対評価および私的 WTP は一般より も有意に小さく, これらの水源と用途の組み合わせの評 価についても, 絶対評価が私的 WTP に反映されていた。 これらの 3 用途については, 行政等担当者は一般市民に 比較すると，私的費用を負担して整備するものではない と認識していたと言える。

\section{7. 本研究の結果に基づく公共事業の意思決定に関する 考察}

本研究においては, 都市分散型水資源の水源と用途に ついて, 一般市民と行政等担当者との選好, 認識には, 上記のようないくつかの相違点があることが分かった。 公共事業の意思決定においては, 必ずしも一般市民の意 見等を考慮する場が設けられているとは限らない。最近 では, 環境アセスメント, パブリックコメント等の手法 の導入が図られていて，一般市民の意見を考慮すること が必要であるという立場に立てば，その有効活用が望ま れる。

パブリックコメントは, ある程度明確な意思を持つ市 民によるものであるのに対して, 本研究のアンケート調 査のような方法は明確な賛成意見, 反対意見を持たない 市民も選好表明に参加できるという手法である。イン ターネット調査の場合には, インターネットアクセスの 手段を有する市民に対象が限定されるという側面もあ り, 結果の解析にバイアスが入らないように注意する必 要もあるが10), インターネット調査を含むアンケート調 査は市民の選好を調査する手法として有効であろう。

水資源のような特に技術的側面が大きなテーマでは, 本研究の結果が示すように, 一般市民と行政等担当者の 選好が乘離する傾向があると思われる。選好の乘離が見
られる部分については, 行政, 事業者等の役割として, 情報発信等による意思疎通が求められる。研究者の役割 は, 双方の選好, 認識等を中立的に解析, 検討すること である。

水資源を対象として AHPを用いて解析を行った先行 研究は, 水道, 下水道関係では事例が限られているが 12,13)，森林における生物多様性と水資源のような枠組み ではAHP と他の意思決定方法を組み合わせた研究が海 外で行われている ${ }^{19 \sim 21)}$ 。本研究は, 複数の比較的使用 量が少ない水源や用途について検討した点, 統計的検定 手法について検討した点においてこの分野の新しい研究 であると言える。

\section{8. おわりに}

都市分散型水資源の水源と用途について, 一般と行政 等担当者を対象にアンケート調査を行った結果を比較検 討した結果, 一般と行政等担当者の選好に有意に相違が あることが分かった。

統計的検定手法の導入により, 重みベクトル, 公的お よび私的 WTP の相違について有意水準を判定基準とす ることができた。統計的検定手法を含む AHP は, 日本 ではあまり導入が進んでいないため, 本研究のような基 礎的知見の蓄積が必要であると考えられた。さらに，本 研究のように一般市民と行政等担当者の選好を比較検討 した研究の結果については, 結果を公開し, 一般市民, 行政等担当者のコミュニケーションの契機とするような ことも今後は必要となる。

水源と用途の組み合わせについて，日本ではまだあま り柔軟に考えられていないところもあり, 国土交通省, 国土技術総合研究所の複数の部署が担当されている。今 後は, 各水源と用途の組み合わせについて, 水量, 年間 変動, 水質と処理の必要性等を整理した一般市民向けの 資料を整備する必要もある。

2 章で示した都市分散型水資源の水資源全体における 位置づけや， 3 章で示した公共事業等の意思決定法に鑑 み, 本研究の結果, AHP を公共事業の意思決定法等に 導入する際の技術的な問題提起と解決法を提示すること ができ，一般市民と行政等担当者との選好等の相違点を 示すことができた。

なお, 本論文は平成 22 年 6 月第 41 回土木学会土木計 画学研究発表会 (春大会) における発表原稿に加筆修正 したものである。本研究により開発した AHP 等の解析 方法について, 特許出願を行った (平成 22 年 4 月 28 日 提出, 特願 2010-104132, 特許出願人: 学校法人東洋大学)。

\section{謝 辞}

本研究は, 国土交通省平成 21 年度建設技術研究開発 助成制度（代表：荒巻俊也）によって実施した。

（原稿受付 2011 年 7 月 14 日) （原稿受理 2011 年 10 月 5 日）

\section{参 考 文 献}

1) 健全な水循環系構築に関する関倸省庁連絡会議 (2003) 神田 川流域水循環系再生構想検討報告 (案), http://www.mlit.go.jp/ tochimizushigen/mizsei/junkan/ (2009年 10 月時点).

2 ) 健全な水循環系構築に関する関係省庁連絡会議 (2003) 寝屋 川流域水循環系再生構想検討報告, http://www.mlit.go.jp/ 
tochimizushigen/mizsei/junkan/ (2009年 10 月時点).

3) 国土交通省 (2006) 都市における未活用水の利用事例〜都市 をうるおす水のみち〜, http://www.mlit.go.jp/river/pamphlet_jirei/ kankyo/gaiyou/panf/water_use/s-1.pdf (2010年2 月時点).

4 ）国土交通省土地・水資源局水資源部（2009）吉野川水系に おける水資源開発基本計画中間評価書, http://www.mlit.go.jp/ tochimizushigen/mizsei/d_plan/ch_05/yoshino.htm(2010年2月時点).

5 ）内閣府大臣官房政府広報室 (2008) 水に関する世論調査, http:// www8.cao.go.jp/survey/h20/h20-mizu/index.html (2009年9月時点).

6 ) 藤井聡 (2001) 土木計画のための社会的行動理論一態度追従型 計画から態度変容型計画へ -, 土木学会論文集, No.688 / IV-53, 19-35.

7 ）木下栄蔵, 大野栄治 (2004) AHPとコンジョイント分析, 228p., 現代数学社, 東京.

8 ) 斎藤順, 平泉光一 (2005) 土地改良事業が果たす公益的機能の 相対的評価, 新潟大学農学部研究報告, 57 (2), 83-88.

9 ) 大塚佳臣, 栗栖 (長谷川) 聖, 花木啓祐 (2009) 河川の物理属性 及び住民の認知に基づく類型化による都市河川の価值評価構造 解析, 環境システム研究論文集, 37, 271-282.

10）大塚佳臣, 栗栖聖, 中谷隼, 花木啓祐 (2011) 水辺環境に着目し た住民の都市河川金銭価值評価解析, 水環境学会誌, 34 (2)，2940.

11）山本充 (1996) 環境用水の導入に係る社会経済的効果の計測・ 評価に関する研究, 商学討究, 小樽商科大学, 46 (4), 177-203.

12) Hosoi, Y. and Kido, Y. (2001) Comparative reliability analysis of the distribution areas of a water supply system and its application for an earthquake risk analysis, Water Science \& Technology: Water Supply, 1 (4), 217-226.

13）三浦浩之, 尾崎平, 和田安彦 (2002) エコデザインによる都市 内水供給システムの再生, 水環境学会誌, 25, 417-424.

14）山縣弘樹, 山中大輔, 荒谷裕介, 南山瑞彦 (2007) コンジョイン 卜分析を用いた下水処理水によるせせらぎ水路の多面的な便益 の評価, 環境システム研究論文集, 35, 287-294.

15） 木村昌弘, 伊藤禎彦 (2007) 持続可能な上下水道システム構築 へ向けた総合評価手法, 環境システム研究論文集, 35, 295-306.

16) Willett, K. and Sharda, R. (1991) Using the analytic hierarchy process in water resources planning: Selection of flood control projects, Socio-Economic Planning Sciences, 25 (2), 103-112.

17) Jaber, J. O. and Mohsen, M. S. (2001) Evaluation of nonconventional water resources supply in Jordan, Desalination, 136 (1-3), 83-92.

18) Hämäläinen, R., Kettunen, E., Marttunen, M. and Ehtamo, H. (2001) Evaluating a Framework for Multi-Stakeholder Decision Support in Water Resources Management, Group Decision and Negotiation, 10 (4) , 331-353.
19) Vacik, H. and Lexer, M. J. (2001) Application of a spatial decision support system in managing the protection forests of Vienna for sustained yield of water resources, Forest Ecology and Management, 143 (1-3), 65-76.

20) Thirumalaivasan, D., Karmegam, M. and Venugopal, K. (2003) AHP-DRASTIC: software for specific aquifer vulnerability assessment using DRASTIC model and GIS, Environmental Modelling \& Software, 18 (7), 645-656.

21) Cai, X., Lasdon, L. and Michelsen, A. M. (2004) Group Decision Making in Water Resources Planning Using Multiple Objective Analysis, Journal of Water Resources Planning and Management, 130 (1) , 4-14.

22）都筑良明, 荒巻俊也 (2009) 都市分散型水資源活用についての 住民選好検討における階層分析法 (AHP) の適用可能性, 環境シ ステム研究論文発表会講演集, 37, 141-147.

23）内閣府大臣官房政府広報室（2001）水に関する世論調查, http:// www8.cao.go.jp/survey/h13/h13-mizu/index.html (2009年9月時点).

24）亀田達也（1997）合議の地を求めてーグループの意思決定, $155 \mathrm{pp}$., 共立出版, 東京.

25) Sen, A. K. (1970) Collective Choice and Social Welfare, 225pp., Holden-Day, San Francisco.

26）佐伯胖 (1980) 決め方の論理, 328pp., 東京大学出版会, 東京.

27）木下栄蔵 (2000) 入門 AHP, 160pp., 日科技連出版社, 東京.

28）椿本晃久（2001）階層化意思決定法における集団の意思決定, 関西学院商学研究, 48, 73-85.

29) Ramanathan, R. and Ganesh, L.S. (1994) Group preference aggregation methods employed in AHP: An Evaluation and an intrinsic process for deriving members' weightages, European Journal of Operational Research, 79, 249-265.

30）国土交通省都市・地域整備局下水道部（2008）下水処理水の再 利用のあり方を考える懇談会資料：懇談会の検討の方向性につ いて, 第 1 回資料 3, http://www.mlit.go.jp/crd/city/sewerage/gyosei/ shorisui/080222/first03.pdf (2009年 9 月時点).

31）国土交通省土地 ·水資源局水資源部（2011）雨水 - 再生水利用 プラットフォーム, http://www.mlit.go.jp/tochimizushigen/mizsei/g_ resources/index_usuisaiseisuiriyo.html (2011 年2月時点).

32）国土技術政策総合研究所気候変動適応研究本部 (2011) 気候変 動による渇水リスク増加に対応した下水処理水の活用方策に関 する研究, http://www.nilim.go.jp/lab/kikou-site/20study/data/data4. pdf (2011年2月時点).

33) Kasuya, E. (2001) Mann-Whitney U test when variances are unequal, Animal Behaviour, 61, 1247-1249.

34）青木繁伸 (2007) 二群の平均值 (代表值) の差を検定するとき, http://aoki2.si.gunma-u.ac.jp/lecture/BF/index.html(2010年12 月時点).

\section{[論 文 要 旨]}

都市分散型水資源 3 種類と用途 5 種類について, 一般市民と行政等担当者を対象にアンケート調査を行い, 両者の選好等を比較検討した。階層分析法 (AHP) の評価基準は, 行政等担当者が一般市民よりも, 安定性 (社 会), 事業費用および期間（経済），水環境（自然）を重視していた。水源の評価は両者とも雨水，下水処理 再生水, 地下構造物浸出水の順であった。用途は両者とも災害用水, 農業・園芸用水の評価が比較的大きかっ た。支払意志額（WTP）については，行政等担当者の公的WTP が全体的に大きく（行政等担当者：4,17221,572 円・人 - $^{-1}$ 年 $^{-1}$ (YPY ), 一般市民: 6,152-17,336 YPY), 私的 WTP が全体的に小さい（行政等担当者: 1,106 -4,044 YPY, 一般市民 : 2,561-5,934 YPY) という結果が得られた。

\section{キーワード : 都市分散型水資源；階層分析法；絶対評価法；統計学的検定法；支払意志額}

